\title{
Optimization and Analysis of Steel Stacks for Weight Reduction.
}

\author{
A.P. Pawar ${ }^{1}$, K.S. Sharma ${ }^{2}$, A.J. Thombrey ${ }^{3}$, D.S. Ramteke ${ }^{4}$, \\ P.R.Magdum, S.P.Gadewar \\ (Department Of Mechanical Engineering, M E.S College Of Engineering,S.P.Pune University,India)
}

\begin{abstract}
In today's highly competent world, it has become very important to design an efficient and cost effective system. Proper analytical and optimum design concepts are needed to design such systems. Steel stacks play an important role in this era of industrialization. Stacks are vertical tall slender structures which discharge chemical waste gases from industries to the atmosphere. The main aim of this paper is to minimize total weight and thus, cost of the steel chimney. Our attempt is to generate data and optimize the various design parameters of steel stack. Weight reduction of steel stack will occur by reducing values of the design variables but to an extent such that the steel stack continues to stand and it does not fail in stress analysis. Wind force calculations, stress calculations and deflection calculations have been done in excel sheet referring to IS 875 and IS 6533. Further optimization of these design parameters have been done referring to BS code guidelines. This excel sheet program will also save an individual's time for manual calculations. Analysis of steel stack has been done using ANSYS WORKBENCH. Optimization techniques play a big role in structural design. The purpose is to find an economic path so that a designer or a decision maker can derive maximum benefit from the available resources.
\end{abstract}

Keywords: Steel Stack, IS: Indian standards, BS: British Standards, UBC: Uniform Building Code, Static wind force, Static wind moment, Stress Analysis, Deformation Analysis

\section{Introduction}

A stack or a chimney is a vertical tall structure through which smoke and combustion gases pass out of a building. Stacks are used to emit the exhaust gases higher up in the atmosphere so that diffusion of gases may take place. Stacks may be constructed of steel or R.C.C. Steel stacks are mainly used in the sugar factories, food processing industries, thermal plants etc[1]. Steel stacks are suited for process work where a short heat-up period and low thermal capacity are required. Also, steel chimneys are economical for height up to 45 to $50 \mathrm{~m}$. [2]. Steel chimneys experience various loads in vertical and lateral directions. Steel stack often experiences wind loads, earthquake loads, and temperature loads apart from self-weight. Tall and slender steel stacks are susceptible to wind action. Hence, wind loading is an important design criteria[3].

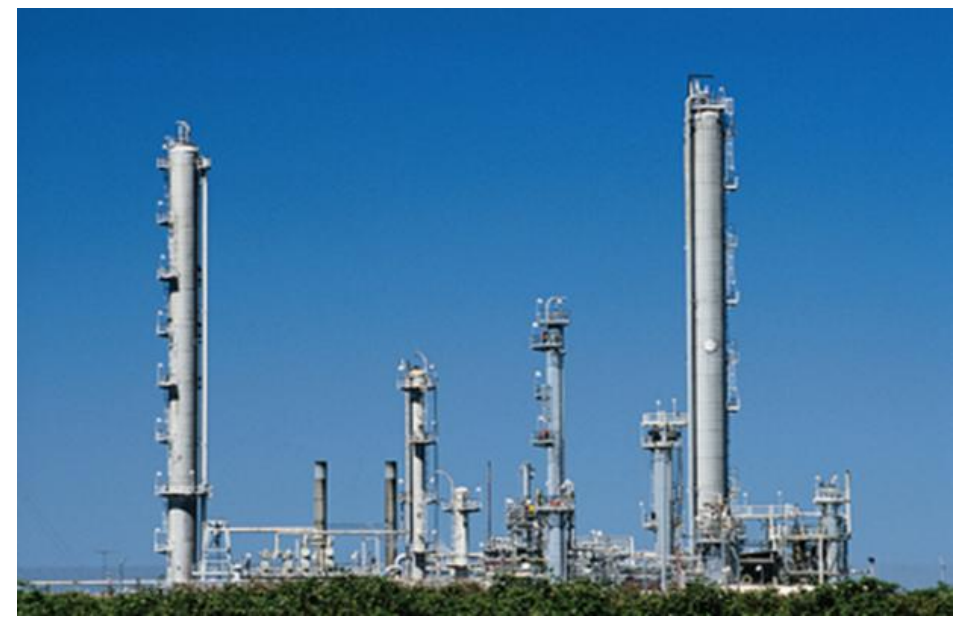

Fig.1 Industrial Steel Stacks

In this work, analysis of steel stack is performed by analytical and simulation for wind loads. The weight of the stack depends on the design variables. These design variables are stack diameters (d), shell thickness (t), and height (h). Wind forces, wind moments, stresses (bending, direct $\&$ total) and deflections are calculated using the input values. The value of allowable stress depends on the type of material used. The 
calculated total stress should be smaller than the allowable stress for steel stack. Similarly, the observed deflections should albe less than the calculated deflections for the stack to stand. In order to optimize the input variables certain iterations have been performed in the excel sheet program considering the stress and deflection checks.

\section{Problem Formulation And Objectives}

Optimization and analysis of steel stack for weight reduction using BS Code guidelines.

i. Finding and finalizing the design parameters of steel stack to be varied.

ii. Optimizing the design variables of the existing steel stack on excel sheet.

iii. Creating a standardized excel sheet program to reduce human efforts and errors.

iv. Simulation and analysis of steel stack using Ansys Workbench.

\section{Wind loads}

\section{Terminology}

The wind force acting on steel stack depends upon its location and height. Wind pressure varies with height. Hence, the stack has to be divided into a number of sections to calculate wind force correctly. The wind pressure acting over each section is assumed to be uniform and the resultant is assumed to be acting at mid-height of that portion. These wind forces result in bending moment in steel stack[4].

\section{Design Wind Pressure}

The design wind pressure at any height above ground level can be calculated by using the following relationship between wind pressure, $\mathrm{P}_{\mathrm{z}}\left(\mathrm{N} / \mathrm{m}^{2}\right)$, and the design wind velocity, $\mathrm{V}_{\mathrm{z}}(\mathrm{m} / \mathrm{s})$ :-

$$
\mathrm{P}_{\mathrm{z}}=0.6 \mathrm{~V}_{\mathrm{z}}^{2}
$$

The coefficient 0.6 in the above equation depends upon a number of factors and primarily on the atmospheric pressure and air temperature. The design wind velocity at any height of steel stack is obtained from the basic wind speed $\left(\mathrm{V}_{\mathrm{b}}\right)$. Basic wind speed depends on the following factors: (1) risk level, (2) terrain roughness, (3) Size and height of structure and (4) local topography. It can be mathematically expressed as:-

Where

$$
\mathrm{V}_{\mathrm{z}}=\mathrm{V}_{\mathrm{b}} \times \mathrm{k}_{1} \times \mathrm{k}_{2} \times \mathrm{k}_{3}
$$

$\mathrm{V}_{\mathrm{b}}=$ basic wind speed

$\mathrm{K}_{1}$ = probability factor (risk coefficient)

$\mathrm{K}_{2}=$ multiplying factor by which the basic wind speed is multiplied to obtain the wind speed at different heights in each terrain category.

$\mathrm{K}_{3}=$ the topography factor.

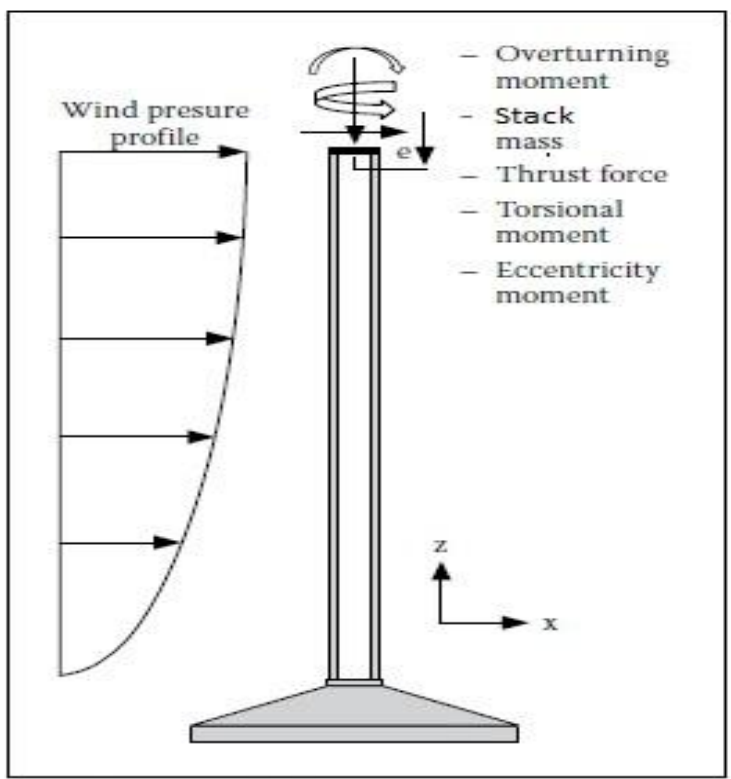

Fig 2. Wind load Profile on steel stacks 
Note:- $\mathrm{k}_{1}$ and $\mathrm{k}_{3}$ are fixed depending upon zone, life of structure, terrain category and class of structure.

$\mathrm{k}_{2}$ varies with height of element.

Terrain category:

It is classified according to the characteristics of ground surface irregularities. They are numbered in increasing order of roughness[5].

\section{Wind Force}

Wind force is the product of wind pressure acting on each segment and surface area at each segment.

\section{Wind shear}

Wind shear is calculated by cumulative addition of wind forces acting on each segment of stack. Wind velocity varies along a direction at right angles to the wind's direction which exerts turning force.

\section{Wind Moment}

Wind moment for each segment is the cumulative sum of product of wind force and vertical distance of each segment.

\section{Analytical Method}

In this work, the input design variables considered are height, diameter and thickness for weight reduction. The steel stack of $35 \mathrm{~m}$ height and $2.4 \mathrm{~m}$ diameter of weight $28754 \mathrm{~kg}$ is considered. Wind velocity considered is $45 \mathrm{~m} / \mathrm{s}$. The temperature of stack is $250^{\circ} \mathrm{C}$. The excel sheet calculations for stresses and deformation have been performed as given below:

Table 1: Input for stack problem

\begin{tabular}{|c|c|c|}
\hline Outer diameter & Inner diameter & Total height \\
\hline 2.4 & 2 & 35 \\
\hline
\end{tabular}

The wind pressure calculations has been done as per UBC 1997 (DIV III)[7]. In our example we have considered the basic wind speed as $45 \mathrm{~m} / \mathrm{s}$.

The design wind pressure has been calculated by the following formula :-

$$
\mathbf{P}_{\mathrm{z}}=\mathrm{C}_{\mathrm{e}} \times \mathrm{C}_{\mathrm{q}} \times \mathrm{q}_{\mathrm{s}} \times \mathrm{l}_{\mathrm{w}}
$$

Where,

$\mathrm{Pz}=$ design wind pressure

$\mathrm{Ce}=$ Combined height, exposure and gust factor coefficient (Refer Table 1)

Table 2: Values of $\mathrm{Ce}$

\begin{tabular}{|r|r|}
\hline \multicolumn{3}{|c|}{ UBC 97 } \\
\hline Mtr & \multicolumn{2}{|c|}{ Ce } \\
\hline 0.0000 & 1.0600 \\
\hline 4.5720 & 1.0600 \\
\hline 6.0960 & 1.1300 \\
\hline 7.6200 & 1.1900 \\
\hline 9.1440 & 1.2300 \\
\hline 12.1920 & 1.3100 \\
\hline 18.2880 & 1.4300 \\
\hline 24.3840 & 1.5300 \\
\hline 30.4800 & 1.6100 \\
\hline 36.5760 & 1.6700 \\
\hline 48.7680 & 1.7900 \\
\hline 60.9600 & 1.8700 \\
\hline 91.4400 & 2.0500 \\
\hline &
\end{tabular}

$\mathrm{Cq}=$ Pressure coefficient of structure

$$
=0.8
$$

$\mathrm{lw}=$ Importance factor $=1$

$\mathrm{qs}=$ Wind stagnation pressure (Corresponding to design wind speed)

$=125 \mathrm{~kg} / \mathrm{sqm}$

Static Wind force on the shell is calculated as

$$
\mathrm{F}=(\mathrm{Do} \times \mathrm{Pz} \times \mathrm{Cf} \times 1) \mathrm{Kg}
$$


Where

Do $=$ Outside diameter of stack

$\mathrm{Cf}=$ Shape factor

Static wind shear at a section is the sum of wind forces acting at sections above it and also includes the wind force at that section.

Direct stress is calculated by

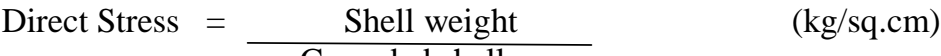

Bending stress is calculated by

$$
\text { Bending stres }=\quad \text { Moment at the Base } \quad(\mathrm{kg} / \mathrm{sq} . \mathrm{cm})
$$

$\mathrm{r}=$ Radius of the shell, in meter

$$
(\mathrm{I} / \mathrm{r})
$$

$\mathrm{I}=$ corroded moment of inertia $\left(\mathrm{m}^{\wedge} 4\right)$

Total Stress is calculated by

$$
\text { Total Stress }=\text { Direct stress }+ \text { Bending stress } \quad(\mathrm{kg} / \mathrm{sq} . \mathrm{cm})
$$

Allowable stress is calculated by taking into account the most adverse temperature to which stack may be expected to exposed[6].

Table3: Temperature coefficient $\mathrm{K}_{\mathrm{t}}$

\begin{tabular}{|c|c|c|c|c|c|}
\hline Temp in C & 200 & 250 & 300 & 350 & 400 \\
\hline $\mathrm{K}_{\mathrm{t}}$ & 1.0 & 0.75 & 0.67 & 0.6 & 0.5 \\
\hline
\end{tabular}

Since the temperature of stack is $250^{\circ} \mathrm{C}$, the value of temperature coefficient is 0.75 .

Stack Deflection is calculated by

$$
\text { Deflection }=\frac{\mathrm{FL}^{3}}{3 \mathrm{EI}}
$$

Where

$\mathrm{F}=$ Wind Force

$\mathrm{L}=$ Length of each segment

$\mathrm{E}=$ Young's Modulus

$\mathrm{I}=$ Moment of Inertia

\section{Numerical Method}

The 3D modelling and analysis of steel stack is done using Ansys Workbench.

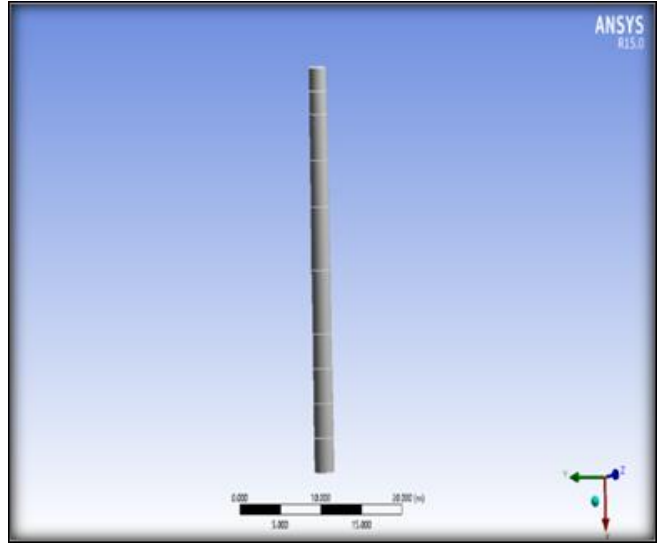

Fig.3a) 3D model of steel stack



Fig.3b) Meshing Model of steel stack

Fig.3a). shows 3D model of steel stack and Fig.3b) shows the meshing model of steel stack. Since, the analysis is being done on steel stack, the material selected is structural steel. The $35 \mathrm{~m}$ steel stack has been divided into 5 sections of varying thickness. Wind forces and wind moments for each section is applied at the centroid of each section of steel stack. Total deformation and stress analysis has been done on steel stack. 


\section{Results And Discussions}

In this paper we have performed the above mentioned wind force, wind moment calculations in the excel sheet.

\section{1) Summary Calculation}

Summary of the excel sheet calculation is as follows:

Table 4-Existing Steel Stack

\begin{tabular}{|c|c|c|c|c|c|c|c|c|c|}
\hline $\begin{array}{l}\text { Elevati } \\
\text { on from } \\
\text { base H } \\
(\mathrm{m})\end{array}$ & $\begin{array}{c}\text { Outsi } \\
\mathrm{de} \\
\text { Dia } \\
\text { Do } \\
(\mathrm{mm})\end{array}$ & $\begin{array}{c}\text { Shel } \\
\text { thic } \\
\mathrm{knes} \\
\mathrm{s} \mathrm{t} \\
(\mathrm{mm} \\
)\end{array}$ & $\begin{array}{c}\text { Static } \\
\text { Wind } \\
\text { Force } \\
(\mathrm{N})\end{array}$ & $\begin{array}{c}\text { Static } \\
\text { Wind } \\
\text { Moment } \\
(\mathrm{N} / \mathrm{m})\end{array}$ & $\begin{array}{c}\text { Tota } \\
1 \\
\text { Stre } \\
\mathrm{ss} \\
(\mathrm{N} /\end{array}$ & $\begin{array}{c}\text { Allow } \\
- \text {-able } \\
\text { stress } \\
(\mathrm{N} / \mathrm{m} \\
\mathrm{mm}^{2} \\
)\end{array}$ & $\begin{array}{c}\text { Total } \\
\text { defle- } \\
\text { ction } \\
(\mathrm{mm})\end{array}$ & $\begin{array}{c}\text { Allow } \\
\text {-able } \\
\text { defle- } \\
\text { ction } \\
(\mathrm{mm})\end{array}$ & $\begin{array}{c}\text { U.C } \\
\text { Ratio }\end{array}$ \\
\hline $0-6$ & 2400 & 20 & 1767.21 & $\begin{array}{c}1920799.3 \\
7\end{array}$ & 23.3 & 70.31 & $\begin{array}{c}0.004 \\
3\end{array}$ & 15 & 0.33 \\
\hline $6-12$ & 2400 & 16 & 2040.32 & $\begin{array}{c}1319817.7 \\
8\end{array}$ & $\begin{array}{c}20.1 \\
3\end{array}$ & 70.31 & 0.14 & 47.5 & 0.29 \\
\hline $12-23$ & 2400 & 12 & 2340.725 & $\begin{array}{c}674581.07 \\
9\end{array}$ & $\begin{array}{c}13.9 \\
7\end{array}$ & 70.31 & 1.28 & 90 & 0.20 \\
\hline $23-31$ & 2400 & 10 & 4437.102 & $\begin{array}{c}158686.56 \\
4.33\end{array}$ & 70.31 & 8.16 & 137.5 & 0.06 \\
\hline $31-35$ & 2400 & 8 & 4632.75 & 11646.92 & 0.6 & 70.31 & 15.98 & 167.5 & 0.008 \\
\hline
\end{tabular}

Output : Total weight of stack $=28754 \mathrm{~kg}$

Table 5-Optimization of steel stack for change in diameter

\begin{tabular}{|c|c|c|c|c|c|c|c|c|c|}
\hline $\begin{array}{c}\text { Elevatio } \\
\text { n from } \\
\text { base } \mathrm{H} \\
(\mathrm{m})\end{array}$ & $\begin{array}{l}\text { Outsi } \\
\text { de } \\
\text { Dia } \\
\text { Do } \\
(\mathrm{mm})\end{array}$ & $\begin{array}{c}\text { Shell } \\
\text { thickne } \\
\text { ss t } \\
(\mathrm{mm})\end{array}$ & $\begin{array}{l}\text { Static } \\
\text { Wind } \\
\text { Force } \\
(\mathrm{N})\end{array}$ & $\begin{array}{c}\text { Static } \\
\text { Wind } \\
\text { Moment } \\
(\mathrm{N} / \mathrm{m})\end{array}$ & $\begin{array}{c}\text { Tota } \\
1 \\
\text { Stres } \\
\mathrm{s} \\
(\mathrm{N} / \\
\mathrm{mm}^{2} \\
)\end{array}$ & $\begin{array}{c}\text { Allow } \\
\text {-able } \\
\text { stress } \\
(\mathrm{N} / \mathrm{m} \\
\left.\mathrm{m}^{2}\right)\end{array}$ & $\begin{array}{c}\text { Tota } \\
1 \\
\text { defle } \\
- \\
\text { ction } \\
\text { (mm } \\
\text { ) }\end{array}$ & $\begin{array}{c}\text { Allow } \\
\text {-able } \\
\text { defle- } \\
\text { ction } \\
(\mathrm{mm})\end{array}$ & $\begin{array}{c}\text { U.C } \\
\text { Rati } \\
\text { o }\end{array}$ \\
\hline $0-6$ & 2200 & 20 & $\begin{array}{c}1619.9 \\
4\end{array}$ & $\begin{array}{c}1760733.8 \\
4\end{array}$ & $\begin{array}{c}25.2 \\
3\end{array}$ & $\begin{array}{c}70.31 \\
3\end{array}$ & $\begin{array}{c}0.00 \\
7\end{array}$ & 15 & 0.36 \\
\hline $6-12$ & 2200 & 16 & $\begin{array}{c}1870.0 \\
3\end{array}$ & $\begin{array}{c}1209832.9 \\
65\end{array}$ & $\begin{array}{c}21.7 \\
9\end{array}$ & $\begin{array}{c}70.31 \\
3\end{array}$ & $\begin{array}{c}0.16 \\
5\end{array}$ & 47.5 & 0.31 \\
\hline $12-23$ & 2200 & 12 & 1960.8 & 539138.87 & $\begin{array}{c}15.1 \\
4\end{array}$ & $\begin{array}{c}70.31 \\
3\end{array}$ & 1.52 & 90 & 0.21 \\
\hline $23-31$ & 2200 & 10 & $\begin{array}{c}3565.2 \\
4\end{array}$ & 145462.68 & 4.65 & $\begin{array}{c}70.31 \\
3\end{array}$ & 9.69 & 137.5 & $\begin{array}{c}0.06 \\
6\end{array}$ \\
\hline $31-35$ & 2200 & 8 & $\begin{array}{c}4314.6 \\
7 \\
\end{array}$ & 10680.64 & $\begin{array}{c}0.62 \\
5 \\
\end{array}$ & $\begin{array}{c}70.31 \\
3 \\
\end{array}$ & $\begin{array}{c}18.9 \\
9 \\
\end{array}$ & 167.5 & $\begin{array}{c}0.00 \\
8 \\
\end{array}$ \\
\hline
\end{tabular}

From Table 6,

Output : Total weight of stack $=26387$

Weight reduction : $8.23 \%$

Output : Total weight of stack $=22827 \mathrm{~kg}$

Weight reduction : $20.61 \%$

In this work, U.C ratio or stress check has been calculated. U.C Ratio is calculated as ratio of total stress to allowable stress. U.C Ratio is less than 0.8 for the considered stack, hence, it is completely safe.In this work deflection check has also been performed. Since deflection is less than allowable deflection of $175 \mathrm{~mm}$ (height/200) hence stack is safe in deflection

\section{2) Software Analysis}

Total deformation and stress analysis has been done on steel stack.

Fig. 4 shows deformation analysis for existing stack 
Optimization And Analysis Of Steel Stacks For Weight Reduction.

Table 6-Optimization of steel stack for change in thickness

\begin{tabular}{|c|c|c|c|c|c|c|c|c|c|}
\hline $\begin{array}{c}\text { Elevati } \\
\text { on from } \\
\text { base H } \\
\text { (m) }\end{array}$ & $\begin{array}{c}\text { Outsi } \\
\text { de } \\
\text { Dia } \\
\text { Do } \\
(\mathrm{mm})\end{array}$ & $\begin{array}{c}\text { Shell } \\
\text { thickn } \\
\text { ess t } \\
(\mathrm{mm})\end{array}$ & $\begin{array}{l}\text { Static } \\
\text { Wind } \\
\text { Force } \\
(\mathrm{N})\end{array}$ & $\begin{array}{c}\text { Static } \\
\text { Wind } \\
\text { Moment } \\
(\mathrm{N} / \mathrm{m})\end{array}$ & $\begin{array}{c}\text { Total } \\
\text { Stress } \\
(\mathrm{N} / \mathrm{m} \\
\left.\mathrm{m}^{2}\right)\end{array}$ & 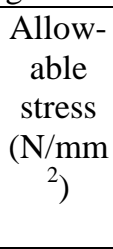 & $\begin{array}{l}\text { Total } \\
\text { defle- } \\
\text { ction } \\
(\mathrm{mm})\end{array}$ & $\begin{array}{l}\text { Allo } \\
\text { w- } \\
\text { able } \\
\text { defle- } \\
\text { ction } \\
\text { (mm) }\end{array}$ & $\begin{array}{c}\text { U.C } \\
\text { Ratio }\end{array}$ \\
\hline $0-6$ & 2400 & 16 & $\begin{array}{c}1767.2 \\
1\end{array}$ & $\begin{array}{c}1920799.3 \\
73\end{array}$ & 28.7 & 70.313 & $\begin{array}{c}0.004 \\
3\end{array}$ & 15 & 0.41 \\
\hline $6-12$ & 2400 & 12 & $\begin{array}{c}2040.3 \\
2\end{array}$ & $\begin{array}{c}1319817.7 \\
8\end{array}$ & 26.45 & 70.313 & 0.14 & 47.5 & 0.38 \\
\hline $12-23$ & 2400 & 10 & $\begin{array}{c}2340.7 \\
25\end{array}$ & $\begin{array}{c}674581.07 \\
92\end{array}$ & 16.53 & 70.313 & 1.28 & 90 & 0.24 \\
\hline $23-31$ & 2400 & 8 & $\begin{array}{c}4437.1 \\
02\end{array}$ & 158686.56 & 5.25 & 70.313 & 8.2 & 137.5 & 0.075 \\
\hline $31-35$ & 2400 & 6 & $\begin{array}{c}4632.7 \\
5\end{array}$ & 11646.923 & 0.73 & 70.313 & 16.06 & 167.5 & 0.01 \\
\hline
\end{tabular}

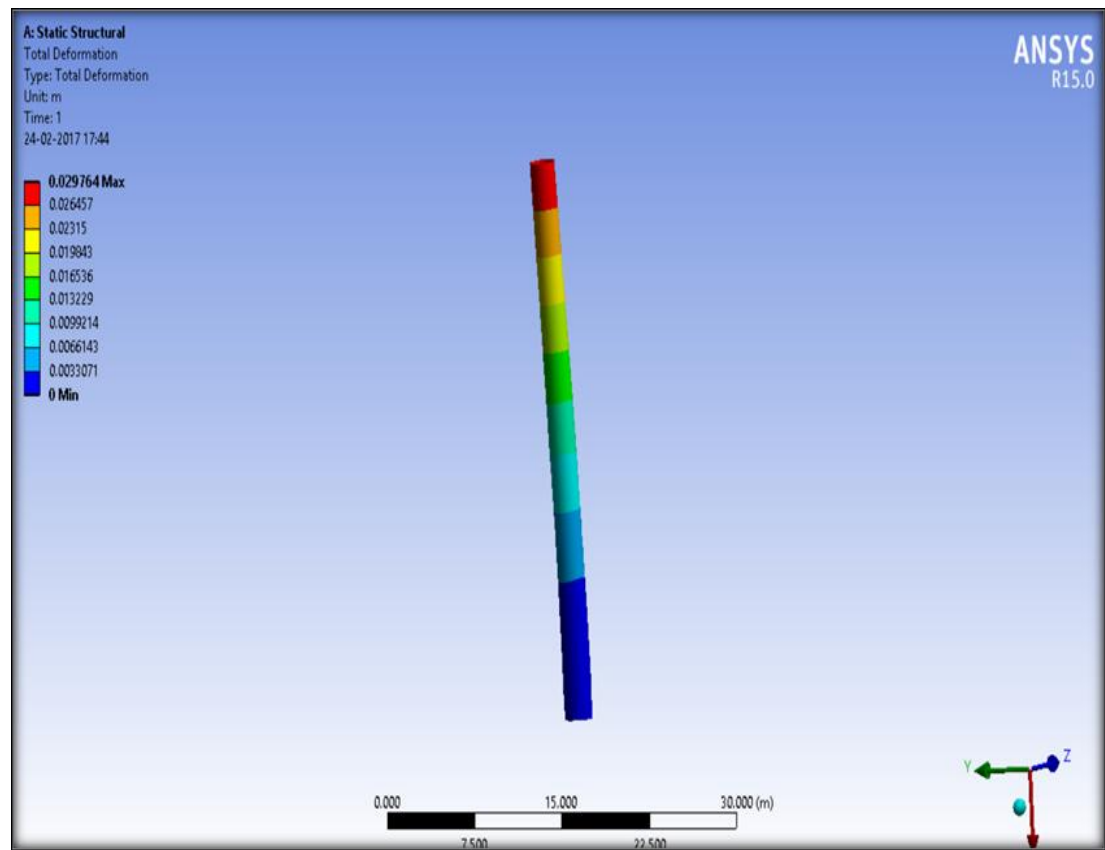

Fig.4. Deformation Analysis on Existing Stack

Fig. 5 shows stress analysis for existing stack and Fig. 6 shows deformation analysis for optimized stack. Fig. 7 shows stress analysis for optimized stack. In the second iteration,diameter is unvaried, hence, the forces and moments acting on stack is same as original.Maximum stress values and deformation values for the existing stack obtained from table 4 is almost similar to the corresponding values obtained from figure 4 and figure 5.Similarly, maximum stress and deformation values for the optimized stack obtained from Table 5 is almost similar to the corresponding values obtained from Figs. 6 and 7. 
Optimization And Analysis Of Steel Stacks For Weight Reduction.

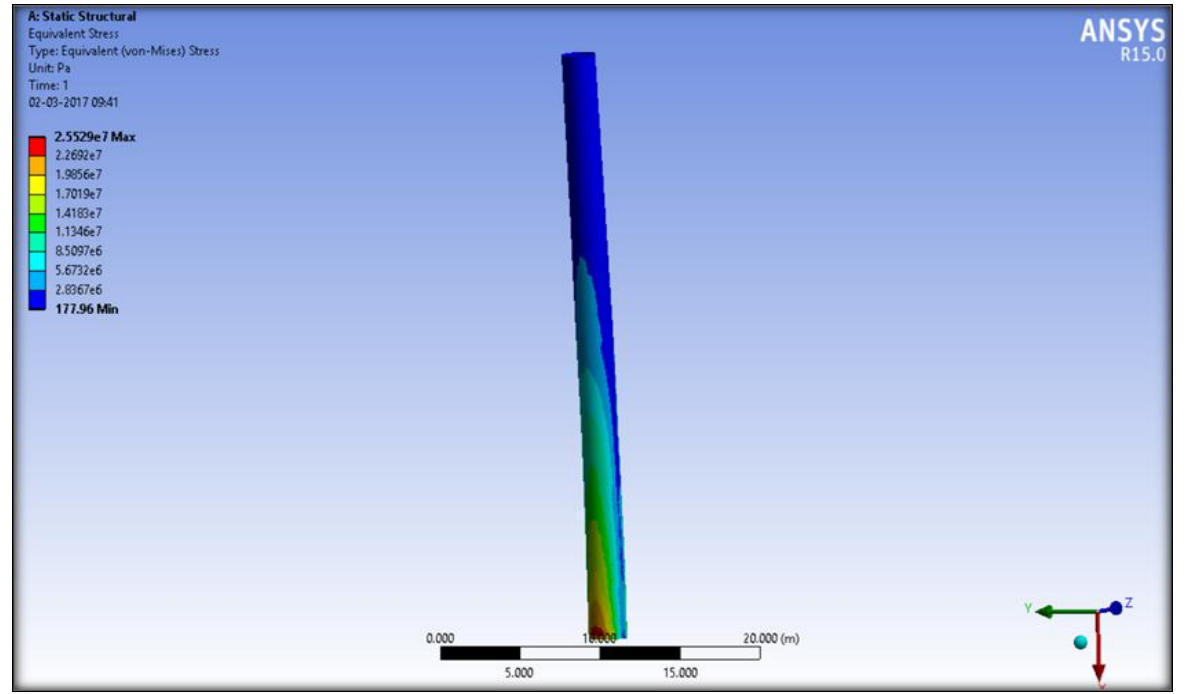

Fig.5.Stress Analysis on Existing Stack



Fig 6 Deformation Analysis on optimized stack

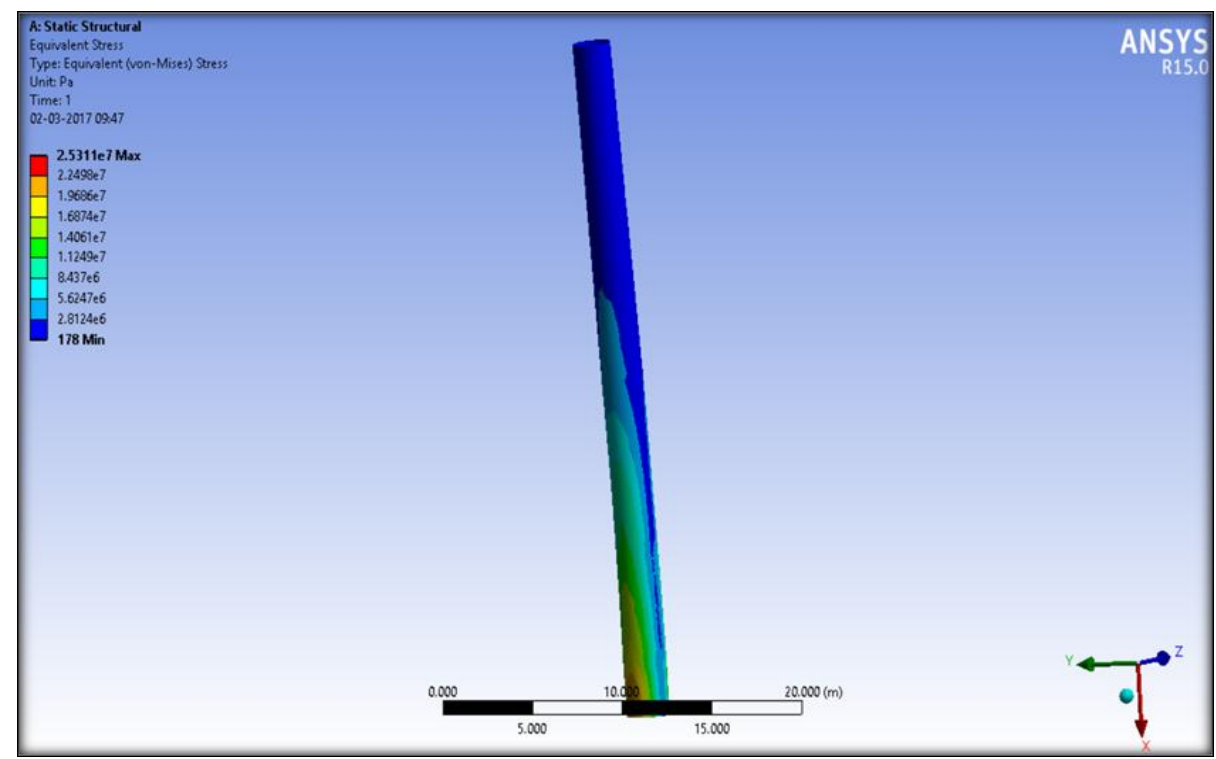

Fig 7 Stress Analysis on optimized stack 


\section{Conclusion}

Two iterations for optimization have been performed on the already existing stack.

- In the first optimization, the outer diameter was reduced from $2.4 \mathrm{~m}$ to 2.2 which resulted in $8.23 \%$ weight reduction.

- In the second optimization, the thickness of varying sections were reduced which resulted in $20.91 \%$ weight reduction

- The design is safe as the ratio of total stress to allowable stress is below the $\operatorname{limit}(<0.8)$.

\section{References}

[1]. G. Murali, B. Mohan, P. Sitara and P. Jayasree, Response of Mild Steel Chimney Under Wind Loads, International Journal of Engineering and Application, 2(2), 2012,490-498.

[2]. B.D.Rakshith, Ranjith A, Sanjith J, Chethan G, Analysis of Cantilever Steel Chimney As Per Indian Standards, International Journal of Engineering and Application, ISSN : 2248-9622, 5(5), 2015, 151-162.

[3]. B. Siva Konda Reddy, V.Rohini Padmavathi , Ch. Srikanth, "Study of wind load effects on tall RC chimneys , International Journal of Advanced Engineering Technology, E-ISSN 0976-3945,3(2), 2012, 92-97 .

[4]. Manoj Kr Gupta, Bajpai V.K, Garg T.K., "Optimization of Design parameters of steel chimneys", International Journal on Design and Manufacturing Technologies,.4(2), 2010, 40-46.

[5]. IS:875 (Part 3) - 1987

[6]. BS $4076: 1989$

[7]. UBC 1997 (DIV III). 